\title{
METABOLIC ALTERATIONS IN EXPERIMENTAL AUTOIMMUNE ENCEPHALOMYELITIS IN MICE: EFFECTS OF PRIOR PHYSICAL EXERCISE
}

\author{
Received June 30, 2014
}

Experimental autoimmune encephalomyelitis (EAE) induces significant reduction of the body mass concomitant to sickness behavior and anorexia. We investigated whether regular physical exercise prevents metabolic alterations associated with loss of the body mass occurring during an EAE inflammatory peak. Female C57BL/6 mice were assigned to the unexercised and exercise-trained groups. In four weeks, EAE was induced in half of the animals in each group, and the exercise protocol was maintained onto 10 days post-induction (10 dpi) completing 6 weeks of regular exercise (forced swimming). At $14 \mathrm{dpi}$, the relative mass of metabolic tissues, serum levels of triglycerides, cholesterol, and glucose, glycogen contents in the muscle and liver, and muscle levels of cytokines were measured. A significantly decreased clinical score associated with attenuation of the body mass loss in exercised EAE animals, as compared to the non-exercised ones, were observed. The associated metabolic parameters were not modified by this approach, although negative correlations between some parameters and clinical score at $14 \mathrm{dpi}$ were observed. Although the prior program of aerobic exercise is capable of decreasing clinical score and body mass loss, it is not sufficient to crucially modify metabolic outcomes associated with inflammation at the EAE peak.

Keywords: experimental autoimmune encephalomyelitis (EAE), physical exercise, cachexia, body mass, metabolic shifts.

\section{INTRODUCTION}

Multiple sclerosis (MS) is a demyelinating disease affecting the CNS and characterized by early inflammation and late neurodegeneration; it leads to muscle weakness, sensory loss, and paresthesia [1]. Experimental autoimmune encephalomyelitis (EAE) is a widely used MS model; it presents a characteristic clinical progression (paralysis) associated with the respective histopathological hallmarks mimicking the MS outcomes [2].

Experimental autoimmune encephalomyelitis is also related to a reduction of the body mass concomitant to sickness behavior including anorexia, which is probably linked to increased levels of the pro-

\footnotetext{
${ }^{1}$ Departamento de Fisiologia e Biofisica, Instituto de Ciências Biológicas, Universidade Federal de Minas Gerais, Belo Horizonte, Brazil.

2 Departamento de Biofisica, Universidade Federal de São Paulo, São Paulo, Brazil.

${ }^{3}$ Departamento de Bioquimica e Imunologia, Instituto de Ciências Biológicas, Universidade Federal de Minas Gerais, Belo Horizonte, Brazil. Correspondence should be addressed to J. Carvalho-Tavares (e-mail julianat@icb.ufmg.br).
}

inflammatory cytokines at a peak of the disease (PD) [3]. Since these molecules stimulate lipolysis and breakdown of muscle proteins, a significant loss of the muscle and fat mass named cachexia can be usually observed [4]. However, the metabolic outcomes underlying the body mass loss in EAE PD have not been examined experimentally.

Because physical exercise was shown to be associated with a reduction in the level of inflammatory cytokines, possible blocking of lipolysis in adipose tissues, and that of muscle protein breakdown, it has been suggested as a promising intervention strategy for both prevention and treatment of cachexia [4]. In terms of prevention, our research group described a systematic protocol of 6-week-long swimming exercise performed prior to the disease development, which led to significant attenuation of EAE clinical score and changes in the body mass from EAE onset to the PD [5]. These data suggested that a regular program of exercise could be a useful strategy for prevention of the cachexia outcomes related to EAE.

Thus, the aim of our study was to investigate whether a regular program of swimming exercise 
alters metabolic events underlying the body mass loss in EAE in mice.

\section{METHODS}

Animals, Design, and Protocols. The Animal Care Facilities of the Universidade Federal de Minas Gerais (UFMG, Brazil) supplied 77 6- to 8-week-old female C57BL/6 mice used in our study. The animals were kept under standard conditions and randomly assigned to the unexercised $(n=40)$ and exercise-trained $(n=$ =37) groups. After four weeks, EAE was induced in half of the animals in each group, and the exercise protocol was maintained until 10 days post induction (dpi). Biochemical and metabolic analyses were performed at $14 \mathrm{dpi}$. The exercise program, EAE induction, and associated clinical score evaluation were performed as previously described $[5,6]$.

Biochemical and Metabolic Analyses. At 14 dpi, mice of all four groups (control, control exercised, EAE, and EAE-exercised) were decapitated. Blood from 5-6 animals in each group was collected and centrifuged, and blood serum was stored at $-20^{\circ} \mathrm{C}$. Tissue samples were collected from 6-7 animals of each group. Parametrial white adipose tissue was weighed and discarded. The gastrocnemius (G) muscles and liver were collected, weighed, and stored at $-20^{\circ} \mathrm{C}$. Serum levels of cholesterol, triglycerides, and glucose were measured using enzymatic kits (Labtest, Barueri, Brazil). Liver and muscle glycogen contents were measured by a colorimetric method, as previously described [6]. Concentrations of IL-6 and TNF in muscle homogenates from additional 7-8 animals were estimated in each group, as previously described [5], using an ELISA setup commercially available (R and D Systems, Minneapolis, USA).

Statistical Analysis. Numerical data expressed below as means \pm s.e.m. were analyzed with GraphPad Prism v.5.0 for Windows using the unpaired $t$-test or MannWhitney test. Correlation analysis between clinical score and the other parameters was also performed using the Pearson test. The statistical significance in intergroup comparisons was set at $P<0.05$.

\section{RESULTS}

Clinical and metabolic data are presented in Tables 1 and 2. Table 1 shows that the 6 -week swimming exercise program was capable of attenuating general data related to clinical score presentation of the disease. Additionally, it can be observed in Table 2 that the body mass loss was moderated in the exercised EAE group, compared to the unexercised EAE one $(P<0.05)$. Besides, significant negative correlations between the clinical score and body mass were observed (unexercised: $r=-0.75, P<0.0001$; exercised: $r=-0.61, P<0.0001)$. Table 2, likewise, demonstrates that the adipose tissue mass and muscle mass in EAE mice were significantly reduced $(P<0.05$ for both indices) compared to the respective values in the control group. EAE mice also showed smaller serum cholesterol, muscle TNF, and IL-6 levels $(P<0.05$ in all cases $)$, as compared to the corresponding values in the control.

$T$ a b l e 1. Clinical parameters of EAE in experimental mice

Т а б л и ц я 1. Клінічні параметри аутоімунного енцефаломісліту в експериментальних мишей

\begin{tabular}{|c|c|c|c|}
\hline Variables & Unexercised EAE mice & Exercised EAE mice & $P$ value \\
\hline Incidence, $\%$ & $\begin{array}{c}100 \% \\
(21 \text { of } 21)\end{array}$ & $\begin{array}{c}100 \% \\
(18 \text { of } 18)\end{array}$ & \\
\hline EAE onset, day & $\begin{array}{c}10.9 \pm 0.34 \\
(11.0)\end{array}$ & $\begin{array}{c}12.06 \pm 0.33 * \\
(12.5)\end{array}$ & 0.0104 \\
\hline Mean clinical score at the disease peak & $\begin{array}{c}3.1 \pm 0.18 \\
(3.0)\end{array}$ & $\begin{array}{c}2.4 \pm 0.20 * \\
(2.0)\end{array}$ & 0.0195 \\
\hline Cumulative disease index & $11.7 \pm 1.13(12.0)$ & $\begin{array}{c}7.4 \pm 0.85 * * \\
(6.5)\end{array}$ & 0.004 \\
\hline
\end{tabular}

F o o t n o t e s: means \pm s.e.m. are shown. Onset is considered when animals showed loss of the tail tone for two consecutive days. The cumulative disease index is calculated as a sum of clinical scores of each animal between $\mathrm{d} 0$ and $\mathrm{d} 14$ after EAE induction and is a measure of the disease severity. The scores were defined as follows: 0 , no clinical signs; 1 , tail paralysis (or loss of the tail tone); 2 , tail paralysis and hindlimb weakness; 3 , hindlimb paralysis, and 4, complete hindlimb paralysis and forelimb weakness. 
T a b l e 2. Metabolic systemic alterations in EAE mice at 14 dpi

Т а б л и ц я 2. Системні зміни метаболізму в мишей з аутоімунним енцефаломіслітом на 14-й день після індукції останнього

\begin{tabular}{|c|c|c|c|c|}
\hline \multirow[b]{2}{*}{ Variables } & \multicolumn{4}{|c|}{ Groups } \\
\hline & $\begin{array}{l}\text { Control } \\
(n=19)\end{array}$ & $\begin{array}{l}\text { Exercised control } \\
\quad(n=19)\end{array}$ & $\begin{array}{c}\text { EAE } \\
(n=21)\end{array}$ & $\begin{array}{l}\text { Exercised EAE } \\
\quad(n=18)\end{array}$ \\
\hline$\Delta$ body mass before EAE, $\%$ & $18.6 \pm 2.1$ & $16.2 \pm 1.3$ & $19.2 \pm 1.4$ & $17.4 \pm 1.3$ \\
\hline$\Delta$ body mass after EAE, $\%$ & $1.1 \pm 1.8$ & $3.2 \pm 2.4$ & $-20.4 \pm 1.6$ & $-15.5 \pm 1.4^{\mathrm{C}}$ \\
\hline Relative mass of adipose tissue & $0.80 \pm 0.05$ & $0.70 \pm 0.07$ & $0.08 \pm 0.06$ & $0.21 \pm 0.07$ \\
\hline Relative mass of liver & $3.71 \pm 0.08$ & $3.98 \pm 0.11$ & $4.33 \pm 0.11$ & $4.32 \pm 0.06$ \\
\hline Serum glucose, mg/dl & $91.0 \pm 13.2$ & $95.8 \pm 8.2$ & $69.7 \pm 5.1$ & $78.6 \pm 11.3$ \\
\hline Serum triglycerides, $\mathrm{mg} / \mathrm{dl}$ & $122.0 \pm 15.3$ & $127.2 \pm 11.7$ & $90.2 \pm 20.7$ & $119.3 \pm 13.2$ \\
\hline Serum cholesterol, mg/dl & $80.3 \pm 5.6$ & $82.42 \pm 4.4$ & $62.8 \pm 5.4$ & $68.2 \pm 2.8$ \\
\hline Muscle IL-6, pg/ml & $72.8 \pm 8.9$ & $54.2 \pm 6.9$ & $29.8 \pm 5.4$ & $30.0 \pm 5.2$ \\
\hline
\end{tabular}

F o o t n o t e s: means \pm s.e.m. are shown. $\Delta$ body mass represents the percentage of the mass gain before the EAE induction (first 4 weeks of exercise protocol) and after EAE induction (from 0 to $14 \mathrm{dpi}$ ).

\section{DISCUSSION}

Results of our study showed that clinical symptoms and the associated body mass loss related to EAE PD are noticeably attenuated by a prior program of regular exercise, and these findings sustain our formed results [5]. In order to investigate possible metabolic associations, we analyzed mass parameters and biochemical indices in these mice. As was shown, increased physical activity reduces manifestations of metabolic disorders [7] and contributes to preservation of the muscle mass [4, 8]. However, none of the variables were significantly modified in our case by the prior program of swim exercise. It should be noted that our exercise protocol did not affect the ability of EAE animals to recruit leucocytes from the periphery into migration toward the CNS parenchyma [5]. Therefore, the effect from pro-inflammatory environment stimulation of both lipolysys and breakdown of muscle proteins [4] is only slightly impacted by the exercise in our study. Nonetheless, some additional comments are desirable.

Animals with EAE presented $90 \%$ reduction of parametrial white adipose tissue compared to the controls. At the same time, the exercised EAE group showed a slaughter magnitude of such reduction (70\%), compared to the exercised control one. There was also inverse correlation between the mass of adipose tissue andd clinical score at $14 \mathrm{dpi}$ for all EAE animals $(r=-0.61, P<0.05)$. The mean serum triglyceride level was $26 \%$ smaller in the unexercised EAE group compared to the control. At the same time, the decrement was $6 \%$ in the exercised EAE group, and inverse correlation with the clinical score $(r=-0.58$, $P=0.058$ ) was observed in this case. Taken together, our data suggest only a light attenuation effect on changes in the fat mass developing due to exercise in EAE. Indeed, we can suggest that the sum of all body fat pads is responsible for the general attenuated mass loss in exercised EAE mice compared to the unexercised ones. The reduced lipid composition data in PD EAE mice are in agreement with previous findings about MS patients during relapse [9-11]. To our knowledge, our report is the first to quantify the specific profile of lipid components of previously exercised EAE mice at PD.

The magnitudes of reduction for the $G$ muscle mass were quite similar to each other in the EAE and control exercised and unexercised groups. At the same time, there was also inverse correlation with the clinical score for both groups $(r=-0.79, P<0.0001)$. The loss of the muscle mass in EAE is also supported by previous studies using EAE in Lewis rats [12]. In these experiments, decreases in the cross-sectional 
areas of all fiber types in the G muscle were observed. However, our data for the first time showed that the $\mathrm{G}$ muscle mass also decreases in exercised EAE mice.

An important observation is the following. Muscle cytokine levels were reduced by around $50 \%$ in the EAE group compared to the control, and a $28 \%$ reduction was found in the exercised groups. On the other hand, while the EAE group showed a $10 \%$ reduction of the muscle glycogen content, compared to the control group, the exercised ones presented a $34 \%$ reduction of this substrate. Therefore, we can speculate that muscle shrinkage in the unexercised EAE group may mostly be caused by protein loss. At the same time, this effect can be started by the loss of the carbohydrate content in the exercised EAE group. It should be noted that the exercised program in control animals increased the muscle and liver glycogen contents $(P<0.05$ in both cases $)$ and reduced the amount of muscle TNF $(P<0.05)$. This data may suggest that the unexercised group had a higher content of carbohydrates to waste before starting heisting of muscle proteins, which may, in turn, influence general lipid metabolism by activation of liver transcript factors, such as carbohydrate-responsive elementbinding protein (ChREBP) [13].

The data on the loss of the muscle mass may also suggest that conduction of the signals to muscles from the CNS is impaired [14]. Although it is believed that this is a transient condition [12], EAE has been associated with the loss of lower motor neurons [15]. On the other hand, six weeks of forced swimming exercise were able to reduce loss of motoneurons and preserve the muscle mass in a model of amyotrophic lateral sclerosis [16]. At 42-43 dpi, our exercised EAE mice demonstrated an attenuated response for spinal cord axonal damage [17]. Whether these results can be associated with preservation of motoneurons or their inputs or even a rescue of muscle mass in the chronic time point of disease, should be elucidated in future.

In general, our results suggest that the reductions in the muscle mass and fat mass jointly contribute to the reduction in the body mass observed in EAE animals. However, despite of some protection of the general body mass, metabolic outcomes that follow the inflammatory peak of EAE, were not significantly modified by previously performed swimming exercise program.

Acknowledgement. This work is a part of the $\mathrm{DB} \mathrm{PhD}$ thesis. It received the financial support from the Conselho Nacional de Desenvolvimento Científico e Tecnológico
(CNPq, Brazil), the Fundação do Amparo a Pesquisa do Estado de Minas Gerais (FAPEMIG, Minas Gerais, Brazil), and the Coordenação de Aperfeiçoamento de Pessoal de Nível Superior (CAPES, Brazil).

The experiments were in agreement with the international ethical standards and approved by the Institutional Animal Care and Use Committees from UFMG (protocol 24/2010); all efforts were made to avoid any unnecessary distress to the animals.

The authors, D. Bernardes, O. C. Oliveira-Lima, T. Vitarelli da Silva, M. A. Juliano, D. Moreira dos Santos, and J. Carvalho-Tavares, declare that there were no conflicts of any kind relating to commercial or financial relations, relations with organizations or persons, which could in any way be associated with the investigation, and to the interrelationship of the coauthors of the article.

\section{Д. Бернардес ${ }^{l}$ О. К. Олівейра-Ліма, Т. Вітареллі да Сілва, М. А. Жуліано ${ }^{2}$ Д. Морейра дос Сантос ${ }^{1}$ Ж. Карвальо-Таварес ${ }^{l}$}

\section{ЗМІНИ МЕТАБОЛІЗМУ ПРИ ЕКСПЕРИМЕНТАЛЬНОМУ АУТОІМУННОМУ ЕНЦЕФАЛОМІЄЛІТІ У МИШЕЙ: ВПЛИВИ ПОПЕРЕДНЬОГО ФІЗИЧНОГО ТРЕНУВАННЯ}

${ }^{1}$ Інститут біологічних наук при Федеральному університеті штату Мінас Жераїс, Белу Орізонте (Бразилія).

${ }^{2}$ Федеральний університет Сан Паулу (Бразилія).

Р е $з$ ю м е

Експериментальний аутоімунний енцефаломієліт (ЕАЕ) викликає істотне зменшення маси тіла, зумовлене хворобливою поведінкою та анорексією. Ми досліджували, чи можуть регулярні фізичні вправи запобігати метаболічним змінам і втраті маси тіла в перебігу запального періоду ЕАЕ. Миші-самиці лінії C57BL/6 були поділені на «нетреновану» та «треновану» групи. Через чотири тижні у половини тварин кожної групи індукували ЕАЕ, і протокол тренувань підтримувався ще 10 днів після індукції цього захворювання. Як тренування використовували примусове плавання. На 14-й день після індукції ЕАЕ у відповідній групі всі миші піддавались евтаназії; вимірювали відносну масу метаболічнозалежних тканин, рівні тригліцеридів, холестеролу та глюкози в сироватці крові, вміст глікогену в м'язах та печінці та рівні цитокінів у м'язах. У «тренованих» тварин 3 ЕАЕ виявлялося вірогідне зменшення оцінки інтенсивності захворювання порівняно 3 відповідним значенням у «нетренованих» мишей; це було асоційоване з обмеженням втрати маси тіла. У використаному варіанті експерименту зміни метаболічних параметрів у «тренованих» і «нетренованих» тварин істотно не розрізнялись, але на 14-й день спостерігалися негативні кореляції між деякими параметрами та клінічними оцінками. Отже, програма попереднього аеробного тренування здатна забезпечувати зменшення як клінічної 
інтенсивності ЕАЕ, так і відносної втрати маси тіла. Проте цей захід не є достатнім, щоб кардинально модифікувати метаболічні наслідки, пов'язані із запаленням на максимумі ЕАE.

\section{REFERENCES}

1. A. Kutzelnigg and H. Lassmann, "Pathology of multiple sclerosis and related inflammatory demyelinating diseases," Handb. Clin. Neurol., 122, 15-58 (2014).

2. M. S. Recks, K. Addicks, and S. Kuerten, "Spinal cord histopathology of MOG peptide 35-55-induced experimental autoimmune encephalomyelitis is time- and score-dependent," Neurosci. Lett., 494, No. 3, 227-231 (2011).

3. Y. Pollak, H. Ovadia, E. Orion, et al., "The EAE-associated behavioral syndrome: I. Temporal correlation with inflammatory mediators," J. Neuroimmunol., 137, Nos. 1/2, 94-99 (2013).

4. D. W. Gould, I. Lahart, A. R. Carmichael, et al., "Cancer cachexia prevention via physical exercise: molecular mechanisms", J. Cachexia Sarcopenia Muscle., 4, No. 2, 111 124 (2013).

5. D. Bernardes, O. C. Oliveira-Lima, T. Vitarelli-Silva, et al., "Differential brain and spinal cord cytokine and BDNF levels in experimental autoimmune encephalomyelitis are modulated by prior and regular exercise," J. Neuroimmunol., 264, Nos. 1/2, 24-34 (2013).

6. D. Bernardes, M. S. J. Manzoni, C. Souza, et al., "Efeitos da dieta hiperlipídica e do treinamento de natação somre o metabolismo de recuperação ao exercício em ratos," Rev.Paul. Educ. Fís. (ISSN 0102-7549. Cessou em 2003. Continuação ISSN 1807-5509, Revista Brasileira de Educação Física e Esporte), 18, No. 2, 191-200 (2004).

7. R. K. Dishman, H. R. Berthoud, F. W. Booth, et al., "Neurobiology of exercise," Obesity (Silver Spring), 14, No. 3, 345-356 (2006).
8. J. M. Argiles, S. Busquets, F. J. Lopez-Soriano, et al., "Are there any benefits of exercise training in cancer cachexia?" J. Cachexia Sarcopenia Muscle, 3, No. 2, 73-76 (2012).

9. W. Cendrowski, W. Szajbel, E. Waszkiewicz, and K. Niedzielska, "Serum lipid studies in multiple sclerosis," Z. Klin. Chem. Klin. Biochem., 6, 423-425 (1968).

10. J. N. Cumings, R. C. Shortman, and T. Skrbic, "Lipid studies in the blood and brain in multiple sclerosis and motor neurone disease," J. Clin. Pathol., 18, No. 5, 641-644 (1965).

11. A. Montfoort, R. W. R. Baker, R. H. S. Thompson, and K. J. Zilkha, "Plasma phospholipids and their fatty acid composition in multiple sclerosis," J. Neurol, Neurosurg, Psychiat., 29, No. 2, 99-102 (1966).

12. A. de Haan, M. R. van der Vliet, J. J. Hendriks, et al., "Changes in characteristics of rat skeletal muscle after experimental allergic encephalomyelitis," Muscle Nerve, 29, No. 3, 369-375 (2004).

13. V. Polacow and A. H. Lancha Jr., "Dietas hiperglicídicas: efeitos da substituição isoenergética de gordura por carboidratos sobre o metabolismo de lipídios, adiposidade corporal e sua associação com atividade física e com o risco de doença cardiovascular," Arq. Bras. Endocrinol. Metab., 51, No. 3, 389-400 (2007).

14. M. Buffelli, E. Pasino, and A. Cangiano, "Paralysis of rat skeletal muscle equally affects contractile properties as does permanent denervation," J. Muscle Res. Cell Motil., 18, No. 6, 683-695 (1997).

15. J. Vogt, F. Paul. O. Aktas, et al., "Lower motor neuron loss in multiple sclerosis and experimental autoimmune encephalomyelitis," Ann. Neurol., 66, No. 3, 310-322 (2009).

16. S. Deforges, J. Branchu, O. Biondi, et al., "Motoneuron survival is promoted by specific exercise in a mouse model of amyotrophic lateral sclerosis," J. Physiol., 587, Part 14, 35613572 (2009).

16. D. Bernardes, R. Branbilla, V. Bracchi-Ricard, et al. "Prior regular exercise improves clinical outcome and reduces demyelination and axonal injury in experimental autoimmune encephalomyelitis," J. Neurochem., 136, Suppl. 1, 63-73 (2015). 